\title{
Police Students' Satisfaction of Courses and Instructors: Does it affect Academic Success?
}

\author{
Murat DELICE * \\ Mehmet ODABAŞI ${ }^{* *}$
}

Received: 13 June 2013

Accepted: 08 April 2014

\begin{abstract}
Assessing the satisfaction levels of students is an important tool for finding the failures of the educational systems and making effective enhancements to increase the quality of the education. This research study assesses second class students' satisfaction levels about the courses and instructors of a police vocational school of higher education and the effect of student satisfaction levels over academic success. Two types of data were collected for this study. The first data includes the satisfaction levels of students about courses and instructors. The second data includes students' final grades. The data sets were analyzed using descriptive statistics, ANOVA, correlation, and multiple regression tests. The findings demonstrated that students are satisfied with both the courses and the instructors; however, satisfaction levels significantly differed based on different courses and instructors. Moreover, a significant positive relationship was found between the satisfaction level of courses and instructors with academic success.
\end{abstract}

Keywords: Student satisfaction, police, academic success.

\section{Extended Abstract}

Purpose and Significance: People are the most valuable resources of nations and the skills that will help people contribute to the nation's development and prosperity can only be acquired through education (Tok \& Sontay, 2006). Education can be described as a process that prepares a ground for physical, psychological, and social development of individuals while they are being integrated to the society as happy and productive citizens (Yeşilyaprak, 2002). Because education affects both the society and the individuals, educational quality must be at a high standard in order to fully benefit from the expected outcomes. Higher student satisfaction, on the other hand, positively affects the education they receive (Atay \& Y1ldirım, 2009; Guolla, 1999).Therefore, assessing the satisfaction levels of students, who are the most prominent stakeholders of educational institutions, is an important tool for finding the failures of the educational systems, making effective enhancements and increasing the quality of the education. This research study assesses second class students' satisfaction levels about the courses and instructors of a police vocational school of higher education and the effect of student satisfaction levels over academic success. It is expected that the findings of the study will help enhance education at the police vocational school of higher education. As a result of the increased quality of education, students will be able to transform into

\footnotetext{
Corresponding Author: PhD., Department Manager in the Turkish National Police, Erzurum, Turkey, muratdelicekos@yahoo.com

${ }^{* * *}$ PhD., Department Manager in the Turkish National Police, Zonguldak, Turkey, mehmetodabasi@ hotmail.com
} 
quality police officers with high standards which in turn will result in a better public service.

Methods: The sample for this study was drawn from second class students of a police vocational school of higher education in Anatolia. Two types of data were collected for this study. The first data was obtained through surveys and includes the satisfaction levels of students about courses and instructors. The surveys were distributed to all second class students and received with a response rate of 93\%. The second data includes students' final grades about seven courses that are mostly taught in classroom settings. The student satisfaction scale which was developed by Gul and Delice (2011) was used for this study. The scale was used in previous studies and was also found to be reliable based on Cronbach's Alpha scores for each part of the survey $(0.63,0.76$ and 0.89).The data sets were analyzed with SPSS 17.0 by using descriptive statistics, ANOVA, correlation, and multiple regression tests.

Results: The first part of the survey included items regarding students' self-evaluation of themselves regarding courses. According to the analysis, students were satisfied about attending courses regularly; however, they had low scores regarding course preparation. The second part of the survey included items regarding courses and the analyses produced an average score of 3, 8 for all seven courses. Considering that the 4 represented "I agree" in the survey, we can conclude that the students were quite satisfied with the courses. The highest scores were for the items that stated "The course plan matched with the course objectives" (4.2) and "This course will be beneficial for my job" (4.1). The third part of the survey included items regarding instructors. According to the analyses, students were highly satisfied with the instructors with an average score of 4.2. The highest scores were for items "The instructor had knowledge about the course" (4.6) and "The instructor used the course time effectively" (4.4) while the lowest score was for the item "Instructor repeated the lessons for better understating of the students" (3.8). The ANOVA test results demonstrated that these satisfaction levels differed significantly for each of the courses and instructors. Furthermore, the analyses revealed a significant positive relationship between the satisfaction level of courses and instructors with the overall course grades. In conclusion, the satisfaction levels explained $59 \%$ of the variance in the course grades.

Discussion and Conclusions: According to the analyses,, the students are quite satisfied with both the courses and the instructors. However, the satisfaction level about instructors was a bit higher than the satisfaction level of courses. Also, the results of the analyses matched the literature in most aspects. As found in the literature, students are mostly satisfied with instructors having sufficient knowledge about the coursework and using the course time efficient enough to convey the course objectives. On the other hand, it is understood that the satisfaction levels differed significantly based on different courses and instructors. Furthermore, the analyses demonstrated that there was a 
significant positive relationship between the satisfaction levels and the course grades. It is clear that students care about courses and instructors so they pay more attention to the courses and instructors and earn higher grades when they are satisfied with them. Therefore, we can conclude that having better instructors will increase the satisfaction level; thus, leading to a quality education. 


\title{
Polis Öğrencilerinin Dersler ve Eğitmenlerden Memnuniyet Düzeyleri: Memnuniyet Akademik Başarıyı Etkiliyor mu?
}

\author{
Murat DELICE*
}

\author{
Mehmet ODABAŞI ${ }^{* *}$
}

Makale Gönderme Tarihi: 13 Haziran 2013

Makale Kabul Tarihi: 08 Nisan 2014

ÖZET: Öğrencilerin memnuniyet düzeyinin ölçülmesi, eğitim sisteminin aksayan yönlerini bularak eğitimin kalitesini artırabilmek adına etkili iyileştirme yapmada kullanılabilecek önemli bir araçtır. Bu araştırmada bir Polis Meslek Yüksek Okulunda eğitim gören 2. sınıf öğrencilerinin aldıkları derslere ve bu derslerin öğretim elemanlarına ilişkin memnuniyet düzeyleri ile bu düzeylerin akademik başarıya olan etkisi incelenmiştir. Araştırmada iki çeşit veri toplanmıştır. Birinci veri öğrencilerin dersler ve öğretim elemanlarına ilişskin memnuniyet düzeyleridir. İkinci veri ise araştırmaya katılan öğrencilerin derslere ait dönem sonu notlarıdır. Araştırmanın verileri betimsel istatistikler, ANOVA, Korelasyon ve Çoklu Regresyon testleri kullanılarak analiz edilmiştir. Bulgular öğrencilerin derslerinden ve öğretim elemanlarından iyi düzeyde memnun olduklarını göstermiştir. Ancak, bulgular, öğrencilerin gerek derslere ilişkin gerekse öğretim elemanlarına ilişkin memnuniyet düzeylerinin derslere ve öğretim elemanlarına göre anlamlı derecede farklılaştığını göstermiştir. Ayrıca, öğrencilerin derslere ve öğretim elemanlarına ilişkin memnuniyet düzeyleri ile bu derslere ait not ortalamaları arasında pozitif yönlü, anlamlı ve güçlü bir ilişki olduğunu anlaşılmıştır.

Anahtar sözcükler: Öğrenci memnuniyeti, polis, akademik başarı.

\section{Giriş}

Öğrenci memnuniyetinin ölçülmesi, eğitimlerin kalitesini artırmak ve eğitimlerden maksimum fayda elde edilebilmek için kullanılabilecek değerli bir araçtır. Öğrencilerin aldıkları eğitimle ilgili memnuniyet düzeylerinin yüksek olması alınan eğitime pozitif yönlü katkı sağlamaktadır (Atay ve Yıldırım, 2009; Guolla, 1999). Yapılan bilimsel araştırmalar öğrenci memnuniyetinin akademik başarı, motivasyon, yaratıcı düşünce, iletişim becerisi, problem çözme yeteneği ve eğitime devamllık gibi değişkenlerle pozitif yönlü ilişkisi olduğunu göstermiştir (Özgüngör, 2008). Öğrencilerin memnuniyet düzeyleri ise eğitimin kalitesi, öğretim elemanları, fiziki mekânlar, sosyal-kültürel-sportif imkânlar, danışmanlık ve öğrencinin bireysel özelliği gibi faktörler tarafindan belirlenmektedir (Sahney, Banwet ve Karunes, 2004; Uzgören ve Uzgören, 2005). Öğrencinin ders ve ders ortamıyla ilgili ihtiyaç ve beklentilerinin karşılanmasıyla onların daha çok memnun olması ve böylece derslere karşı daha çok güdülenmeleri, derse ilgilerinin artması ve katılım düzeylerinin yükselmesi beklenmektedir (Gömleksiz, 2002). Bu ve benzeri etkenlerin öğrenci memnuniyetine etkilerinin ölçülmesi, aksayan yönlerin tespit edilmesi ve memnuniyet arttırıcı uygulamaların yapılmasıyla eğitimin kalitesinin arttrılması mümkün olabilmektedir (Tatl1, Kokoç ve Karal, 2011). Böylece hem öğrencilerin hem de eğitim kurumlarının başarıları artmış olacaktır.

Ülkelerin sahip oldukları en değerli kaynak insan kaynağıdır ve insan kaynağına ülkenin gelişimine ve refahına katkı sağlayacak nitelikleri kazandırmak da ancak

\footnotetext{
*Sorumlu Yazar: Doç. Dr. Erzurum İl Emniyet Müdürlügü̈, Şube Müdürü, Erzurum, muratdelicekos@yahoo.com *** Dr. Zonguldak İl Emniyet Müdürlüğü, Şube Müdürü, Zonguldak, mehmetodabasi@ hotmail.com
} 
eğitimle mümkündür (Tok ve Sontay, 2006). Eğitim bireyin bedensel, psikolojik ve toplumsal gelişimine zemin hazırlayan ve onları toplumla bütünleşmiş, mutlu ve üretken yapan bir süreç olarak tanımlanabilir (Yeşilyaprak, 2002). Eğitim, bireylerin istenmeyen davranışlarının istenene çevrilmesi ve bireye yeni beceriler kazandırılması için kullanılan bir araçtır (Ertürk, 1972). Eğitim sadece öğrenciye yapılan bir hizmet değildir; eğitimin iş dünyasının ve toplumun geliştirilmesinde de önemli rolleri vardır (Iş1k, 2012). Eğitim, bireye kişisel yeterlilik ve hayata tutunabilme ve mücadele edebilme yeteneği kazandırırken aynı zamanda iş dünyasının ihtiyaç duyduğu kaliteli hizmet ve ürün üretebilmek için de nitelik kazandırır (Tok ve Sontay, 2006). Böylece hem kaliteli hizmet ve ürün üretilebilir hem de kişisel refah mümkün hale gelir. Bu ikisinin olması da toplumsal refaha destek olur.

Eğitim hem bireyi hem de toplumu etkileyen bir süreç olduğundan eğitimden beklenen faydanın elde edilebilmesi için eğitimin kaliteli olması gereklidir. Kalite, örgütlerin hayatlarını devam ettirebilmeleri ve etkili rekabet edebilmeleri için edinmeleri gereken bir değerdir (İçli ve Vural, 2010). Günümüzün değişen şartları, görsel medyanın ve internetin yaygınlığı örgütlerin kaliteye olan gereksinimini daha da arttırmıştır. Günümüzde her alanda olduğu gibi eğitim alanında da rekabet, hizmetlerin yürütülmesini önemli boyutlarda etkilemektedir ve küreselleşmenin de etkisiyle rekabet uluslararası boyutlara taşınmıştır (Ekinci ve Burgaz, 2007). Eğitim kurumları, daha kaliteli eğitimin peşinde olan öğrencileri kendilerine çekebilmek için performans ve kalite düzeylerini artırmanın çabası içerisindedirler. Hatta eğitim kalitesinin arttırılmasının ve sürdürülmesinin eğitim kurumlarının varlıklarını devam ettirebilmeleri için kaçınılmaz bir şart olduğu vurgulanmaktadır (Sökmen, 2011).

Kalite ise müşterinin beklentilerinin karşılanması ve hatta beklentilerinin de ötesine geçilmesidir (Parasuraman, Zeithaml ve Berry, 1985). Hizmetlerin hangi kalitede verildiği kadar müşterinin verilen hizmetleri nasıl algıladığı da önemlidir. Müşteri aldığı mal veya hizmet hakkında ihtiyaç ve beklentilerinin karşılandığını düşünüyorsa o mal veya ürünün kaliteli olduğunu da düşünecektir (Düren, 2000; Yenersoy, 1997). Müşterinin ihtiyaç ve beklentileri hesaba katılmadan üretilen ürün ve hizmetin satışı karlı olmayacaktır (Şahin, 2009). Bu nedenle, müşterinin sunulan hizmet hakkında ihtiyaç ve beklentileri bilinmeli ve bu ihtiyaç ve beklentiler doğru olarak ölçülmelidir (Okumuş ve Duygun, 2008).

Eğitim veren örgütlerin de kalite standartlarını belirlemek ve bu doğrultuda performanslarını artırabilmek için kullanabileceği önemli araçlardan bir tanesi eğitimin paydaşlarının verilen hizmetlerle ilgili algı ve memnuniyet düzeylerinin ölçülmesidir (Popli, 2005). Eğitim kurumlarının verdiği hizmetten etkilenen ve bu hizmetlerle ilgili bir memnuniyet tutumu geliştirebilen farklı paydaşlar vardır. Bunlar; öğrenciler, öğrenci velileri, eğitim veren kurumun kendi personeli, mezuniyet sonrası istihdam sağlayan ekonomi çevreleri, devlet kurumları, yerel yönetimler ve toplumdur (Politis ve Siskos, 2004). Eğitim kurumunun verdiği eğitimin kalitesi olumlu ya da olumsuz olarak bu tarafları etkilemektedir. Kaliteli eğitim memnuniyet verici olandır ve tüm bu tarafların gelişimine katkı sağlayandır (Kaya ve Engin, 2007). Eğitim kurumları öğrencilerin, 
öğrenci velilerinin ve toplumun beklenti ve ihtiyaçlarına karşıllk verebilirlerse verdikleri hizmetlerden memnuniyet sağlayabilirler ve böylece başarıya ulaşılması kolaylaşmış olur (Briggs; 2006; Ensari ve Onur, 2003).

Eğitim hizmetlerinin doğrudan ve en önemli müşterisi öğrencilerdir. Eğitim veren örgütlerin verdiği hizmetlerle ilgili öğrencilerde oluşan alg1 düzeyleri öğrenci memnuniyeti anketleri ile ölçülmektedir (Ekinci ve Burgaz, 2007). Bu anketler öğrencilerin memnuniyet düzeylerini gösterdiği kadar öğrencilerin hangi konulara daha çok önem verdiğini de işaret etmektedirler. Bu anketlerden elde edilecek bulgular eğitim hizmetlerinin aksayan yönlerini gösterdiği gibi eğitim hizmetlerini geliştirmek ve kalitesini arttırmak için de kullanılabilmektedir.

Öğrenci memnuniyetini farklı alanlarda ölçen pek çok araştırma hem yurtdışında hem de ülkemizde yapılmıştır. Ancak, öğrenci memnuniyeti ve akademik başarı arasındaki ilişkiyi ölçen araştırmaların sayısı sınırlıdır. Bu araştırmada Anadolu'da bir Polis Meslek Yüksek Okulu (PMYO) 2. sınıf öğrencilerinin dersler ve öğretim elemanları ile ilgili memnuniyet düzeyleri ölçülmüş ve memnuniyet düzeyleri ile öğrencilerin akademik başarıları arasındaki ilişki incelenmiştir. Araştırmanın bulgularının PMYO'da verilen eğitimin kalitesinin arttırılmasına katkı sağlaması hedeflenmiştir. Eğitim kalitesinin arttırılmasıyla öğrenciler günümüz koşullarına uygun ve beklenen standartlarda birer polis olabilecekler ve ülkemize verilen güvenlik hizmetinin de kalitesi arttırılmış olacaktır. Araştırmanın verileri 22 soruluk bir anketle toplanmıştır ve betimsel istatistikler, ANOVA, Pearson Product Moment Korelasyon ve Çoklu Regresyon testleri kullanılarak analiz edilmiştir.

\section{Literatür Taraması}

Öğrenci memnuniyetini etkileyen pek çok faktör vardır. Bu faktörlerin öğrenci memnuniyeti üzerine etkileri güvenilirlik, karşılık verebilirlik, güvence, empati ve fiziksel yeterlilik boyutlarında ölçülebilmektedir (Emanuel ve Adams, 2006; Okumuş ve Duygun, 2008): Güvenilirlik boyutu; derslerin programa uygun ve zamanında yapılmasını, öğrenci kayıtlarının hatasız tutulmasını ve öğrencilerin karşılaştığı sorunlar karşısında sorumluları bulabilmesini, öğretim elemanının ders için hazırlanmasını, interaktif yöntemler kullanarak dersi etkili bir şekilde işlemesini ve bu doğrultuda öğrenciyi güdülemesini kapsar. Karşıllk verebilmek boyutu; derslerin zamanı ve yapılış şekli bilgilerinin öğrencilere bildirilmesini, öğrenci hizmetlerinin hızlı şekilde verilebilmesini ve çalışanların öğrencilere hizmet etmeye hazır ve istekli olmasını, öğrencilerin ihtiyaç ve sorunları karşısında muhatap bulabilmesini ve bu hizmetin gönüllü ve samimi bir şekilde yapılmasını kapsamaktadır. Güvence boyutu; eğitim görevlilerinin yeterli bilgi ve beceriye sahip olmasını, iletişim becerilerinin yüksek olmasını, ulaşılabilir olmalarını, öğrenciye karşı saygılı, ilgili ve samimi olmalarını, öğrencilerinin şikâyet ve önerilerinin dinlemesini, öğrencilerin eğitimle ilgili meydana gelen aksaklıklardan zamanında haberdar edilmesini, öğrencilerin kişisel kayıtlarının güvenliğine azami dikkat edilmesini, öğrenciye sunulan hizmetlerde ve davranışlarda güvenilir, tutarlı, açık ve net olmayı kapsamaktadır. Empati boyutu ise; öğrencilerin beklenti ve ihtiyaçlarının anlanmasını, farklılıklarına saygı gösterilmesini, değer 
verilmesini ve bunun öğrencilere hissettirilmesini, ayrıca anlatımlarının öğrencinin anlayacağı düzeyde olmasını kapsamaktadır. Son olarak, fiziksel varlıklar boyutu; eğitim ortamının fiziksel görüntüsünün yeterliliğini, ortamın temiz ve düzenli olmasını, ders yapmaya uygun olmasını ve eğitim materyallerinin yeterliliğini kapsamaktadır (Emanuel ve Adams, 2006; Okumuş ve Duygun, 2008).

Ayrıca, Emanuel ve Adams (2006) öğrenci memnuniyeti ölçülürken öğretim elemanlarının aşağıdaki etkenler açısından değerlendirilmeleri gerektiğine de vurgu yapmıştır: Ders konusuna hâkim olma, ders anlatmada uygun teknik ve yöntemler kullanma, kalıcılığı sağlayıcı teknikler kullanma, konuları açık, net ve anlaşı1ır bir şekilde öğrencilere sunma, konuyu somut ve güncel örneklerle açıklama, öğrencilerin derse katılımını teşvik etme, kendisine yöneltilen soruları ikna edici bir şekilde cevaplama, ders dişında kendisiyle iletişim kurulabilme. Sökmen (2011) de eğitim hizmetlerinin insan odaklı olduğunu, çoğu zaman eğitim hizmetinin bir insan aracılığıyla diğer insanlara aracısız ve yüz yüze sunulduğunu, bu nedenle memnuniyet düzeyi incelenirken bu etkenin göz ardı edilmemesi gerektiğini belirtmiştir. Benzer olarak, öğrencinin memnuniyet düzeyini sadece ders sürecinin belirlemediği ve öğrencinin derste ve sonrasında öğretim elamanıyla ilişkilerinin de önemli bir etken olduğu vurgulanmıştır (Ekinci ve Burgaz, 2007). Ders sonrası öğretim elemanıyla etkili ve sağlıklı iletişim kurabilen öğrencilerin özgüvenlerinin daha yüksek olduğu, bu öğrencilerin gelecekteki kariyerleri hakkında daha fazla düşünsel yoğunluk yaşadıkları ve memnuniyet düzeylerinin daha yüksek olduğu da belirtilmektedir (Ekinci ve Burgaz, 2007).

Öğrenci memnuniyetini araştıran pek çok bilimsel çalışma bu boyutlar üzerinden memnuniyet düzeyini ölçmüşlerdir. Ülkemizde öğrenci memnuniyeti ilköğretim okullarından üniversitelere kadar geniş bir yelpazede araştırılmıştır. Bu araştırmaların öğrenci memnuniyeti ile ilgili bulguları dersler ve öğretim elemanları açısından benzerlik göstermektedir. Okumuş ve Duygun (2008) öğrencilerin hizmet kalitesi algısıyla memnuniyet düzeyleri arasında pozitif yönlü anlamlı bir ilişki olduğunu göstermişler ve yukarıda ifade edilen beş boyuta ait şartların iyileştirilmesiyle öğrenci memnuniyetinin arttığını bulmuşlardır.

Ekinci ve Burgaz (2007) da öğrencilerin öğretim elamanı ile ilgili beklenti düzeylerinin yüksek ancak memnuniyet düzeylerinin düşük olduğunu bulmuşlardır. En yüksek memnuniyet düzeyinin öğretim elemanının derslere zamanında gelmesiyle, en düşük memnuniyet düzeyinin ise geri bildirim olarak nitelenebilecek öğrencilerin dersteki durumları hakkında bilgilendirme yapılmasıyla ilgili olduğu bulunmuştur. Farklı fakülteler arasında öğretim elemanı değerlendirmeleri açısından da anlamlı farklılıklar bulunmuştur.

Benzer olarak, Burgaz ve Ekinci (2007) Hacettepe Üniversitesi’nde öğrencilerin akademik, danışmanlık, sosyal, sağlık, yönetim, beslenme vb. hizmetlere ilişkin memnuniyet düzeylerini ölçmüşlerdir. Akademik hizmet olarak; öğretim elemanlarının derslere hazırlıklı gelmesi, dersi severek işlemesi, derslerden sonrada ulaşılabilir olmaları ve öğrencilerin öğretim elemanlarından yeterli destek alabilmeleri etkenleri 
ölçülmüştür. Bulgular bu konularda beklentilerinin yüksek (4.1), ancak memnuniyet dizeylerinin orta (2.7) olduğunu göstermiştir. Ayrıca, her bir akademik hizmet için yapılan değerlendirme diğerlerine göre anlamlı derecede farklılaşmaktadır. $\mathrm{Bu}$ araştırmada da fakülteler arasında memnuniyet düzeyleri anlamlı derece farklılaşmaktadır.

Y1ld1z, Erdemir ve Gitmez (2006) bir orta öğretim kurumunda öntest-sontest yöntemiyle yaptıkları araştırmalarında 2 yıl arayla öğrencilerin, okullarının sunduğu farklı hizmetler hakkında memnuniyet düzeylerini ölçmüşlerdir. Bulgular, okulun öntest sonuçlarına göre yapılan iyileştirme ve geliştirme çalışmalarının pek çok alanda öğrencilerin memnuniyet düzeyini anlamlı derecede arttırdığını göstermiştir. Bu bulgu, öğrencilerin memnuniyet düzeyinin yapılan çalışmalarda arttırılabileceğini göstermesi açısından önemlidir. Ayrıca çalışmada öğretmenlere istenilen zaman ulaşılabilme, anlamadığını sorabilme, sorulan soruyla ilgili öğretmenin yeterince ilgilenmesi, öğretmene güvenme, öğretilenlerin hayatta işe yararlığı, derse yeterli sürenin ayrılmış olması, ders kitaplarının konuya uygun seçilmiş olması, derse uygun yeterli materyalin bulunması ifadeleri için memnuniyet düzeyi hem öntest hem de sontest için 4.0 puanının üstünde ve yüksek düzeyde bulunmuştur. Okulun ve sınıfın fiziksel ortamı ile ilgili (büyüklük, aydınlatma, ergonomi gibi) değerlendirmeler ise 2.0 puanı civarında ve düşük düzeyde bulunmuştur.

Tok ve Sontay (2006) öğretim elemaniyla istenilen zamanda görüşme, anlamadığını sorabilme boyutları için memnuniyet düzeyini orta (yaklaşık 3.3), yeterli ders materyalinin bulunması için yüksek (3.6) ve öğretilenlerin hayata uygulanabilmesi için çok yüksek olarak (3.9) bulmuşlardır. Özgüngör (2008) de akademik kalite (3.9) ve öğrenci-öğretim elemanı ilişkisinin (3.9) doyum düzeyi yüksek boyutlardan olduğunu göstermiştir. Kampus yaşantısı ve teknolojik imkânlarla ilgili memnuniyet daha düşük bulunmuştur. Yukarıdaki araştırmalara paralel olarak, program türüne göre memnuniyet düzeylerinin anlamlı derecede değiştiği bulunmuştur.

İçli ve Vural'ın (2010) bir meslek yüksekokulunda yaptığı araştırmanın bulgularına göre öğretim elemanlarıyla ilgili en yüksek memnuniyet düzeyleri öğretim elemanlarının derslerine önem vermeleri ve iyi hazırlanmaları (3.9), derslere zamanında gelmeleri ve zamanı etkin kullanmaları ifadeleri içindir. En düşük memnuniyet düzeyleri ise teknik geziler düzenlenmesi ve meslekten birilerinin derse getirilmesi ifadeleri içindir (2.7). Derslerle ilgili en yüksek memnuniyet düzeyi sinavlar güvenli bir şekilde ve kopya çekilmeden yapılmaktadır ifadesi içindir (3.8). En düşük ise laboratuvar imkânları ve materyal yeterliliği içindir (2.1). Bulgular fiziksel yeterlilikle ilgili memnuniyet düzeyinin yüksek olduğunu göstermiştir. Öğretim elemanları değerlendirmelerinde bazı ifadelerinin meslek okullarına göre farklılaştığı da bulunmuştur.

Sökmen (2011) de bir meslek lisesinde yaptığı araştırmada öğrencilerin en fazla öğretim elemanlarının yeterli bilgi ve beceriye sahip oldukları ifadesi için memnuniyet gösterdiklerini ve öğrencilerin memnuniyet düzeylerinin bölümlere göre değiştiğini bulmuştur. Başka bir araştırmada da ERASMUS öğrencilerinin öğretim elemanları ve 
akademik hizmetlerle ilgili memnuniyet düzeyinin yüksek olduğu ve en yüksek memnuniyet düzeyinin öğretim elemanının derse hazırlıklı gelmesiyle ilgili olduğu bulunmuştur (Yağc1 ve diğerleri, 2007).

Kaya ve Engin'in (2007) bulguları ise derslerin beklentileri karşılama düzeyinin orta ile iyi düzey arasında olduğunu, derslerin verimi ile ilgili değerlendirmenin ise iyi düzeyde olduğunu göstermiştir. Öğretim elemanın ders anlatma yeterliliği, dersi örneklerle anlatması ve ders işleme saatine uyumu ile ilgili değerlendirmeler iyi ve yüksek düzeyde bulunmuştur. Öğretim elemanının öğrenciye karşı tutum ve davranışına ilişkin memnuniyet de yüksek düzeyde bulunmuştur. Bununla beraber farklı dersler ve derslerin öğretim elemanları değerlendirmelerinin de birbirine göre farklılaştığı gözlemlenmiştir.

Şahin (2009) öğrenci memnuniyet düzeyini üç yıl arka arkaya aynı ölçekle ölçmüştür. Bulgular hem derslerden hem de öğretim elamanlarından memnuniyetin uygulama yıllarına göre ve üniversite ana bilim dallarına göre farklılık gösterdiğini işaret etmiştir. Öğrencilerin hem derslerden hem de öğretim elemanlarından orta düzeyde memnun oldukları ancak öğretim elemanı memnuniyet düzeyinin nispeten daha yüksek olduğu bulunmuştur.

Öğrenci memnuniyeti ile ilgili üzerinde durulması gereken diğer önemli bir konu da dersler ve öğretim elemanlarının özelliklerinin bütün öğrencilerde aynı düzeyde memnuniyete sebep olmadı̆̆ıdır. Öğrencilerin demografik özellikleri ve bireysel farklılıkları da memnuniyet düzeyini etkilemektedir. Işık (2012) üniversite öğrencilerinin memnuniyet düzeyini ölçmüş ve memnuniyet düzeylerini cinsiyet, ebeveyn eğitim seviyesi, milliyet gibi değişkenler açısından karşılaştırmıştır. Bulgular Kıbrıs'tan gelen yabancı öğrencilerin memnuniyet düzeyinin daha yüksek olduğunu göstermiştir. Baba eğitim seviyesine göre de öğrencilerin memnuniyet düzeyi anlamlı derecede değişmektedir. Ebeveyn ile beraber kalan öğrencilerin memnuniyet düzeyi kirada kalanlardan daha yüksektir. Özgüngör (2008) de üniversiteyi tercih nedenlerine göre memnuniyet düzeyinin anlamlı derece farklılaştığını bulmuştur. Dolayısıyla bireysel özelliklere göre memnuniyetin değiştiği söylenebilir.

Yukarıda ifade edilen öğrenci memnuniyeti üzerine yapılmış çalışmaların bulgularını şu şekilde özetlemek mümkündür: genel olarak, öğretim elemanlarına ait memnuniyet düzeyi derslere ait memnuniyet düzeyinden daha yüksek olarak ölçülmüştür. Öğrencilerin memnuniyet düzeyleri fakültelere, programlara ve derslere göre farklılaşmaktadır. Öğrencilerin memnuniyet düzeyleri ayrıca öğrencilerin bireysel özelliklerine göre de farklılaşmaktadır. Son olarak, eğitim kurumlarında yapılan iyileştirmelerle öğrencilerin memnuniyet düzeyleri arttırılabilmektedir.

\section{Yöntem}




\section{Evren ve Örneklem}

$\mathrm{Bu}$ araştırma Anadolu'da bir PMYO'da yapılmıştır. Bu araştırma sırasında okul yetkililerinden alınan bilgilere göre PMYO'lar Polis Eğitim Merkezleri ile birlikte Emniyet Teşkilatının polis memuru ihtiyacını karşılayan iki eğitim kurumundan birisidir. Türkiye genelinde toplam 28 PMYO her yıl yaklaşık 15000 öğrenci ile eğitim öğretim faaliyetlerini sürdürmektedir. Bu evren içinde araştırmanın yapıldığı PMYO araştırmacıların en kolay ulaşabileceği bir araştırma alanı olduğundan olasılıklı olmayan bir örnekleme yöntemi olan keyfi örnekleme yöntemiyle seçilmiştir.

İki yıllık bir eğitim süresine sahip olan bu PMYO'larda eğitim gören öğrencilerin, Polis Teşkilatında görev alabilecek nitelik ve özelliklere sahip olarak mezun edilebilmesi PMYO'ların en belirgin hedefidir. $\mathrm{Bu}$ bağlamda verilen eğitim çerçevesinde dört dönemlik bir eğitim müfredatı uygulanmaktadır.

$\mathrm{Bu}$ araştırmada 2.sınıf öğrencilerinin Güz dönemi içerisinde eğitim aldıkları derslerden sınıf ortamında teorik olarak anlatılan İnsan Hakları, Polis Meslek Etiği, Mesleki Uygulamalar, Halkla İlişkiler ve İletişim, Ceza Hukuku, Mesleki İngilizce ve Adli Yazışma ve Soruşturma Kuralları dersleri değerlendirilmiştir. Silah Bilgisi ve Yakın Savunma gibi uygulamalı dersler bu araştırmanın dışında tutulmuştur.

Araştırmaya okuldaki bütün 2. sınıf öğrencileri dâhil edilmişlerdir. Araştırmada iki çeşit veri toplanmıştır. Birinci veri anketlerle toplanılan öğrencilerin dersler ve öğretim elemanlarına ilişkin memnuniyet düzeyleridir. İkinci veri ise araştırmaya katılan öğrencilerin, aldıkları derslere ait dönem sonu not ortalamalarıdır ki bu veriler gerçek verilerdir ve okul idaresinden alınmıştır. Anketler öğrencilere dönem sonunda final sınavları öncesinde sınıflarında dağıtılmıştır. Anketlerin dağıtılması sırasında öğrencilere araştırmanın amacı ve araştırmaya katılmanın gönüllü olduğu açıklanmıştır. 185 öğrenci anketi doldurmuştur ki bu sayı tüm 2. sınıfların \%93’ü kadardır.

Bütün 2. sınıf öğrencileri beş şubeden oluşmaktadır. Her bir şube aynı isim ve formatta yukarıda isimleri verilen yedi dersi almaktadır. Derslere de aynı öğretim elemanları girmektedir. Böylece öğrenciler anketlerde yedi aynı dersi ve yedi aynı öğretim elamanını değerlendirmişlerdir.

\section{Veri Toplama Araçları}

Araştırmanın verileri Gül ve Delice (2011) tarafından geliştirilen bir öğrenci memnuniyeti ölçeği kullanılarak toplanmıştır. Ölçek, beş aşamalı bir değerlendirmenin olduğu 21 sorudan oluşan Likert tipi bir ölçektir. 1 hiç katılmıyorum'u karşılarken, 5 tamamen katılıyorum'u karşılamaktadır. Ayrıca, bütün sorular pozitif yönlü olarak sorulmuştur. Ölçek 3 bölümden oluşmaktadır. Ölçeğin orijinalinde birinci bölümde 3 soru ile öğrenci öz değerlendirmesi, ikinci bölümde 6 soru ile ders değerlendirilmesi ve üçüncü bölümde ise 12 soru ile öğretim elemanı değerlendirilmesi yapılmaktadır. Ölçeğin Cronbach Alpha güvenirlik katsayıları bölümler için sırasıyla 0.63, 0.76 ve 0.89 olarak bulunmuş ve ölçek güvenilir olarak rapor edilmiştir (Gül ve Delice, 2011).

$\mathrm{Bu}$ ölçek, yukarıda literatür taraması kısmında bahsedilen öğrenci memnuniyetini etkileyen güvenilirlik, karşılık verebilirlik, güvence, empati ve fiziksel 
yeterlilik boyutları açısından literatür de kullanılarak bu araştırma için tekrar gözden geçirilmiş ve revize edilmiştir. Gözden geçirme ve revize işlemlerinde PMYO yetkililerinin desteği alınmıştır. Yeni halinde ölçek yine aynı üç bölümden oluşmaktadır, ancak soru sayısı değişikliklerle beraber 23'e yükseltilmiştir. Birinci bölüm aynı 3 sorudan oluşmaktadır. İkinci bölümdeki "dersin yapıldığı ortam huzur vericiydi" ve "bu dersi başkalarına tavsiye ederim" soruları ölçekten çıkarılmış ve yerlerine "dersin içeriği ve işlenişi ile ilgili dönem başında yazılı bilgilendirme yapıldı", "dersin yapıldığı fiziksel ortam dersi işlemeye elverişli idi" ve "bu dersten öğrendiklerimin meslek hayatında faydalı olacağını düşünüyorum” soruları eklenmiştir. Revize edilmiş ölçekte ikinci bölüm 7 sorudan oluşmaktadır. Öğretim elemanlarının değerlendirildiği üçüncü bölümde bütün dersler zorunlu olduğu için ve öğrencilerin öğretim elemanı seçme şansı olmadığ 1 için "bu öğretim elemanını başkalarına tavsiye ederim" sorusu çıkarılmıştır. Bu bölüme "görsel ve işitsel materyallerle ders anlatımını destekledi” ve "dersin işlenmesinde kullanılan yazılı materyaller yeterliydi” olmak üzere iki yeni soru eklenmiş ve bu bölüm 13 sorudan oluşmuştur. Ölçeğin bütün soruları ve bölümleri Tablo 1'de görülebilmektedir.

\section{Verilerin Analizi}

Araştırmanın verileri SPSS 17.0 programı üzerinde betimsel istatistikler, ANOVA, Korelasyon ve Çoklu Regresyon testleri kullanılarak analiz edilmiştir. Analizler için iki farklı SPSS dosyası kullanılmıştır. Birinci dosyada anketlerdeki 23 değerlendirme sorusu birer değişken olarak oluşturulmuştur. 185 öğrencinin yaptığ değerlendirmeler bu değişkenlerin parametrelerini oluşturmuştur. Öğrencilerin kendilerini, derslerini ve öğretim elamanlarını değerlendirme ortalamaları ve bu ortalamaların 7 derse göre farklılaşıp farklılaşmadığı bu birinci veri dosyası kullanılarak hesaplanmıştır. Öğrencilerin derslerden ve öğretim elemanlarından memnuniyet düzeyi ile ders notları arasındaki ilişkiyi analiz etmek için ikinci bir veri dosyası oluşturulmuştur. Bilimsel etik kuralları gereği anketlerdeki değerlendirmelerin hangi öğrenciye ait olduğu tespit edilmemiştir. Dolayısıyla birinci veri dosyasındaki her bir öğrencinin değerlendirmesinin yanına başka bir değişken olarak ders notu eklenememiştir. Bunun yerine, öğrenci memnuniyeti ve ders notu arasındaki ilişkiyi ölçmek için her bir şubedeki her bir derse ait ders notu ortalaması ile bu dersle ilgili öğrencilerin ders ve öğretim elamanına ilişkin değerlendirmelerinin ortalamaları arasındaki ilişki incelenmiştir. 5 şube ve 7 ders olduğundan birinci veri dosyası kullanılarak 35ders notu ortalaması, 35 ders değerlendirmesi ortalaması ve 35 öğretim elemanı değerlendirmesi ortalaması hesaplanmış ve bu şekildeikinci SPSS dosyası oluşturulmuştur. Korelasyon ve Çoklu Regresyon analizleri bu ikinci veri dosyası kullanılarak yapılmıştır.

Çoklu Regresyon analizlerinde, ders notu ortalamaları bağımlı değişken, öğrencilerin ders ve öğretim elamanına ilişkin değerlendirmelerinin ortalamaları ise bağımsız değişkenler olarak kullanılmıştır. Verilerin Çoklu Regresyon analizlerine uygun olup olmadığını test etmek için veri sayısının yeterli olup olmadığı, normal dağılım ve sabit varyans (homoscedasticity) varsayımları ölçülmüştür. Shavelson (1996) 
Çoklu Regresyon analizlerinde her bir bağımsız değişken için 15 adet verinin yeterli olduğunu belirttiğinden 35 adet verinin iki bağımsız değişken için yeterli olduğu kabul edilmiştir. Bağımlı ve bağımsız değişkenlerin normallik hesaplaması KolmogorovSmirnov testi ile yapılmış ve dağılımların normal olduğu bulunmuştur (her üç değişken için de $p>0.05$ ). Sabit varyans (homoscedasticity) varsayımının ölçümü için ZRESID ve ZPRED dağılımlarına bakılmış ve dağılımların doğrusal olduğu, yani varsayımı sağladığı görülmüştür.

\section{Bulgular}




\section{Tablo 1}

Ögrencilerin Kendileri, Dersler ve Öğretim Elemanları Hakkında Yaptıkları Değerlendirmeler

\section{DERSLER ve ORTALAMALARI}

SORULAR

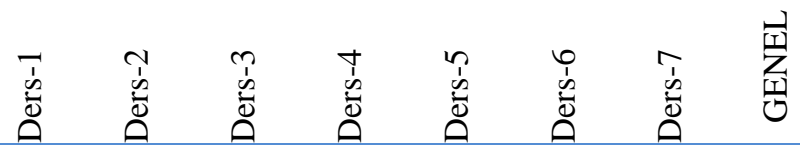

Öğrenci Öz Değerlendirme Soruları

\begin{tabular}{llllllllll}
1 & Derse düzenli ve devamlı olarak devam & 4.7 & 4.7 & 4.7 & 4.6 & 4.6 & 4.7 & 4.7 & 4.7 \\
2 & Derse genellikle konularla ilgili & 2.8 & 2.8 & 3.0 & 2.9 & 2.6 & 3.4 & 2.8 & 2.9 \\
3 & Derse ilgiliydim & 4.2 & 4.1 & 4.6 & 3.7 & 3.4 & 4.2 & 4.0 & 4.0 \\
Öğrenci Öz Değerlendirme Toplam & 3.9 & 3.9 & 4.1 & 3.7 & 3.5 & 4.1 & 3.8 & 3.9 \\
\hline
\end{tabular}

Ders Değerlendirme Soruları

\begin{tabular}{llllllllll}
1 & Dersin içeriği dersin amacına uygundu & 4.6 & 4.6 & 4.7 & 3.9 & 4.1 & 4.6 & 3.4 & 4.2 \\
2 & Dersin içeriği ve işlenişi ile ilgili & 3.8 & 3.8 & 3.9 & 3.5 & 3.4 & 4.0 & 3.4 & 3.7 \\
& dönem başında yazılı bilgilendirme & & & & & & & & \\
3 & Dersin yapıldı̆̆ fiziksel ortam dersi & 3.5 & 3.7 & 4.0 & 3.7 & 3.8 & 3.9 & 2.7 & 3.6 \\
4 & Dersin verilmesi için sınıfta yeterli & 3.6 & 4.0 & 4.1 & 3.8 & 3.8 & 4.0 & 2.9 & 3.7 \\
5 & Bu ders sonunda çok şey öğrendim & 4.3 & 4.1 & 4.3 & 2.8 & 3.3 & 3.8 & 3.4 & 3.7 \\
6 & Bu dersten çok yararlandım & 4.3 & 4.0 & 4.3 & 2.8 & 3.2 & 3.8 & 3.4 & 3.7 \\
7 & Bu dersten öğrendiklerimin meslek & 4.7 & 4.2 & 4.5 & 3.4 & 3.9 & 3.7 & 3.9 & 4.1 \\
& hayatında faydalı olacağını & & & & & & & & \\
Ders & Değerlendirme Toplam & 4.1 & 4.0 & 4.3 & 3.4 & 3.6 & 4.0 & 3.3 & 3.8 \\
\hline Öğretim Elemanı Değerlendirme Soruları & & & & & & & & \\
\hline 1 & Derslere zamanında gelerek zamanı & 4.8 & 4.8 & 4.8 & 2.8 & 4.2 & 4.9 & 4.3 & 4.4 \\
2 & Ders konusuna vâkıftı & 4.7 & 4.8 & 4.9 & 4.1 & 4.6 & 4.8 & 4.1 & 4.6 \\
3 & Konuyu açık,net ve anlaşılır bir şekilde & 4.7 & 4.8 & 4.7 & 3.1 & 3.5 & 4.7 & 3.8 & 4.2 \\
4 & Derse kendisi yeterli zaman ayırdı & 4.7 & 4.7 & 4.7 & 2.8 & 4.2 & 4.6 & 4.2 & 4.3 \\
5 & Konuların işlenmesinde uygun yöntem & 4.4 & 4.6 & 4.7 & 3.1 & 3.4 & 4.5 & 3.9 & 4.1 \\
6 & Dersin işlenmesinde kullanılan yazılı & 4.2 & 4.4 & 4.4 & 3.2 & 4.0 & 4.3 & 3.4 & 4.0 \\
7 & Konuyu somut ve güncel örneklerle & 4.7 & 4.8 & 4.8 & 3.6 & 3.8 & 4.3 & 4.3 & 4.3 \\
8 & Öğrencilerin derse katılımını teşvik etti & 4.2 & 4.3 & 4.7 & 4.0 & 3.2 & 4.6 & 4.3 & 4.2 \\
9 & Kendisine yöneltilen soruları ikna edici & 4.7 & 4.7 & 4.8 & 4.1 & 4.3 & 4.7 & 4.3 & 4.5 \\
10 & Kalıcılığı sağlayıcı tekrarlar yaptı & 4.3 & 4.2 & 4.4 & 2.9 & 3.2 & 4.3 & 3.6 & 3.8 \\
11 & Kullanılan not verme sistemi yeterli ve & 4.6 & 4.5 & 4.6 & 3.6 & 3.5 & 4.6 & 4.1 & 4.2 \\
12 & Derslere anlatılacak konu ile ilgili & 4.8 & 4.8 & 4.8 & 3.4 & 4.0 & 4.7 & 3.9 & 4.3 \\
13 & Görsel ve işitsel materyallerle ders & 3.8 & 4.6 & 4.8 & 3.3 & 2.7 & 4.3 & 4.1 & 3.9 \\
Öğretim Elemanı Değerlendirme Toplam & 4.5 & 4.6 & 4.7 & 3.4 & 3.7 & 4.6 & 4.0 & 4.2 \\
\hline
\end{tabular}


Öğrencilerin, kendileri, dersler ve öğretim elemanları hakkında yaptıkları değerlendirmeler yedi ayrı ders için ayrı ayrı olarak ve bu yedi dersin ortalaması olarak (genel) Tablo 1'de gösterilmiştir. Tabloda sunulan bulgulardan, yedi ders için de öğrencilerin, dersleri düzenli ve sürekli devam etme düzeyleri yüksek, derslere ilgi düzeyleri orta ve derslere hazırlıklı gelme düzeyleri ise düşük bulunmuştur. $\mathrm{Bu}$ konularda yedi derse ait ortalamalar sırasıyla 4.7, 4.0 ve 2.9 olarak ölçülmüştür. Öğrencilerin derslere ait değerlendirmelerinin ortalamaları ise 3.6 ile 4.2 arasında değişmektedir. Derslere ait değerlendirmelerinin genel ortalaması 3.8 olarak ölçülmüştür. Değerlendirmelerde 4 değerinin katılıyorum ifadesini karşıladı̆̆ hatırlanırsa öğrencilerin derslere ilişkin memnuniyet düzeyinin iyi olduğu söylenebilir. Öğrencilerin derslerle ilgili en yüksek memnuniyet düzeyleri derslerin amacına uygunluğu (4.2) ve derslerde ögrenilenlerin meslek hayatında yararlı olacă̆ (4.1) konularında ölçülmüştür. Öğrencilerin derslerle ilgili en düşük memnuniyet düzeyleri ise derslerin yapıldı̆̆ fiziksel ortamın uygunluğu (3.6) ile ilgili olarak ölçülmüştür. Öğrencilerin öğretim elemanları ile ilgili memnuniyet düzeyleri ise daha yüksek ölçülmüştür. Bu konudaki değerlendirmelerin yedi öğretim elemanı için ortalamaları 3.8 ile 4.6 arasında değişmektedir. Öğretim elemanlarına ait değerlendirmelerin genel ortalaması ise 4.2 olarak ölçülmüştür. En yüksek memnuniyet düzeyleri, ögretim elemanının ders konusuna vakıf olması (4.6) ve derslere zamanında gelerek zamanı etkin kullanması (4.4) konularında ölçülmüştür. Öğretim elemanlarının en az memnuniyet sağladıkları konu kalıcılı̆̆ sağlayıcı tekrarlar yapmaları (3.8) olmuştur. Bununla beraber bu ortalamanın bile katılıyorum ifadesini karşıladı̆̆ öğretim elamanlarının bu konuda da öğrenciler tarafindan olumlu olarak değerlendirildiği söylenebilir.

Tablo 2'de ise öğrencilerin, kendileri, dersler ve öğretim elemanları hakkında yaptıkları değerlendirmeler yedi ayrı ders için ayrı ayrı olarak gösterilmiş ve bu değerlendirmelerin yedi ders için anlamlı olarak farklılaşıp farklılaşmadığını test eden Varyans Analizi (ANOVA) bulguları sunulmuştur. Tablodaki bulgular 23 ayrı değerlendirmenin 22'sinde ortalamaların yedi ayrı ders için anlamlı derecede farklılaştı̆̆ını göstermiştir. Başka bir deyişle; öğrencilerin dersler, öğretim elemanları ve kendileriyle ilgili memnuniyet düzeyleri yedi ayrı ders ve öğretim elemanına göre anlamlı düzeyde değişmektedir.Derse ve öğretim elemanına göre farklılaşmanın olmadığı tek boyut ögrencilerin derse düzenli ve devaml olarak katılmasıdır.Araştırmanın yapıldığı PMYO’da derslere devam zorunludur.Bu nedenle bu boyut açısından bir farklılaşmanın olmaması doğaldır. 
Tablo 2

Değerlendirme Farklılıklarının ANOVA Analizi Sonuçları

DERSLER ve ORTALAMALARI

\begin{tabular}{|c|c|c|c|c|c|c|c|c|c|}
\hline \multicolumn{2}{|c|}{ SORULAR } & $\overrightarrow{\dot{\omega}}$ & $\begin{array}{l}\tilde{y} \\
\dot{\omega} \\
\tilde{D} \\
0\end{array}$ & $\begin{array}{l}\tilde{y} \\
\dot{\omega} \\
\tilde{D}\end{array}$ & $\begin{array}{l}\dot{y} \\
\dot{\omega} \\
0\end{array}$ & $\begin{array}{l}n \\
\dot{b} \\
\stackrel{5}{0} \\
0\end{array}$ & $\begin{array}{l}0 \\
\dot{1} \\
\omega \\
0 \\
0\end{array}$ & $\begin{array}{l}\hat{1} \\
\dot{\tilde{\omega}} \\
\stackrel{0}{0}\end{array}$ & $\mathrm{~F}$ \\
\hline \multicolumn{10}{|c|}{ Öğrenci Öz Değerlendirme Soruları } \\
\hline 1 & Derse düzenli ve devamlı olarak & 4.7 & 4.7 & 4.7 & 4.6 & 4.6 & 4.7 & 4.7 & 0.9 \\
\hline 2 & Derse genellikle konularla ilgili & 2.8 & 2.8 & 3.0 & 2.9 & 2.6 & 3.4 & 2.8 & $9.1^{*}$ \\
\hline 3 & Derse ilgiliydim & 4.2 & 4.1 & 4.6 & 3.7 & 3.4 & 4.2 & 4.0 & $5.6^{*}$ \\
\hline & enci Öz Değerlendirme Toplam & 3.9 & 3.9 & 4.1 & 3.7 & 3.5 & 4.1 & 3.8 & $17.7^{*}$ \\
\hline \multicolumn{10}{|c|}{ Ders Değerlendirme Soruları } \\
\hline 1 & Dersin içeriği dersin amacına & 4.6 & 4.6 & 4.7 & 3.9 & 4.1 & 4.6 & 3.4 & $41.9^{*}$ \\
\hline 2 & $\begin{array}{l}\text { Dersin içeriği ve işlenişi ile ilgili } \\
\text { dönem başında yazılı bilgilendirme }\end{array}$ & 3.8 & 3.8 & 3.9 & 3.5 & 3.4 & 4.0 & 3.4 & $7.7^{*}$ \\
\hline 3 & Dersin yapıldığı fiziksel ortam dersi & 3.5 & 3.7 & 4.0 & 3.7 & 3.8 & 3.9 & 2.7 & $15.1^{*}$ \\
\hline 4 & Dersin verilmesi için sınıfta yeterli & 3.6 & 4.0 & 4.1 & 3.8 & 3.8 & 4.0 & 2.9 & $20.6^{*}$ \\
\hline 5 & Bu ders sonunda çok şey öğrendim & 4.3 & 4.1 & 4.3 & 2.8 & 3.3 & 3.8 & 3.4 & $54.0^{*}$ \\
\hline 6 & $\mathrm{Bu}$ dersten çok yararlandım & 4.3 & 4.0 & 4.3 & 2.8 & 3.2 & 3.8 & 3.4 & $51.5^{*}$ \\
\hline 7 & $\begin{array}{l}\text { Bu dersten öğrendiklerimin meslek } \\
\text { hayatında faydalı olacağını }\end{array}$ & 4.7 & 4.2 & 4.5 & 3.4 & 3.9 & 3.7 & 3.9 & $32.3^{*}$ \\
\hline & Değerlendirme Toplam & 4.1 & 4.0 & 4.3 & 3.4 & 3.6 & 4.0 & 3.3 & $46.2 *$ \\
\hline \multicolumn{10}{|c|}{ Öğretim Elemanı Değerlendirme Soruları } \\
\hline 1 & Derslere zamanında gelerek zamanı & 4.8 & 4.8 & 4.8 & 2.8 & 4.2 & 4.9 & 4.3 & $37.8^{*}$ \\
\hline 2 & Ders konusuna vâkıftı & 4.7 & 4.8 & 4.9 & 4.1 & 4.6 & 4.8 & 4.1 & $32.5^{*}$ \\
\hline 3 & Konuyu açık, net ve anlaşı1ır bir & 4.7 & 4.8 & 4.7 & 3.1 & 3.5 & 4.7 & 3.8 & $93.9 *$ \\
\hline 4 & Derse kendisi yeterli zaman ayırdı & 4.7 & 4.7 & 4.7 & 2.8 & 4.2 & 4.6 & 4.2 & $124.0^{*}$ \\
\hline 5 & Konuların işlenmesinde uygun & 4.4 & 4.6 & 4.7 & 3.1 & 3.4 & 4.5 & 3.9 & $68.0^{*}$ \\
\hline 6 & Dersin işlenmesinde kullanılan yazılı & 4.2 & 4.4 & 4.4 & 3.2 & 4.0 & 4.3 & 3.4 & $15.4^{*}$ \\
\hline 7 & Konuyu somut ve güncel örneklerle & 4.7 & 4.8 & 4.8 & 3.6 & 3.8 & 4.3 & 4.3 & $46.8^{*}$ \\
\hline 8 & Öğrencilerin derse katılımını teşvik & 4.2 & 4.3 & 4.7 & 4.0 & 3.2 & 4.6 & 4.3 & $43.0^{*}$ \\
\hline 9 & Kendisine yöneltilen soruları ikna & 4.7 & 4.7 & 4.8 & 4.1 & 4.3 & 4.7 & 4.3 & $22.1 *$ \\
\hline 10 & Kalıcılığı sağlayıcı tekrarlar yaptı & 4.3 & 4.2 & 4.4 & 2.9 & 3.2 & 4.3 & 3.6 & $50.3^{*}$ \\
\hline 11 & Kullanılan not verme sistemi yeterli & 4.6 & 4.5 & 4.6 & 3.6 & 3.5 & 4.6 & 4.1 & $37.0^{*}$ \\
\hline 12 & Derslere anlatılacak konu ile ilgili & 4.8 & 4.8 & 4.8 & 3.4 & 4.0 & 4.7 & 3.9 & $62.8^{*}$ \\
\hline 13 & Görsel ve işitsel materyallerle ders & 3.8 & 4.6 & 4.8 & 3.3 & 2.7 & 4.3 & 4.1 & $73.1^{*}$ \\
\hline \multicolumn{2}{|c|}{ Öğretim Elemanı Değerlendirme Toplam } & 4.5 & 4.6 & 4.7 & 3.4 & 3.7 & 4.6 & 4.0 & $99.0 *$ \\
\hline
\end{tabular}

$\mathrm{N}=185$

* Ortalamalar arasindaki farkl1lık 0.01 seviyesinde anlamlı 
Tablo 3'te araştırmada kullanılan ölçeğin Cronbach Alpha güvenirlik katsayıları gösterilmiştir. Yedi ayrı dersin ve öğretim elemanının değerlendirilmesi yapıldı̆̆ 1 için güvenirlik katsayıları da ayrı ayrı ve ayrıca yedi dersin ortalaması için de hesaplanmıştır. Bulgulara göre öğrenci öz değerlendirme ölçeği için Cronbach Alpha güvenirlik katsayıları 0.14 ile 0.57 arasında, derslerin değerlendirmesi için 0.60 ile 0.81 arasında ve öğretim elamanı değerlendirmesi için 0.83 ile 0.94 arasında değişmektedir. Nunnally (1978) güvenirlik katsayıları için 0.70 ve üzerini ideal, 0.50 ve üzerini ise kabul edilebilir değerler olarak belirtmektedir. Bu kritere göre ders değerlendirme ve öğretim elemanı değerlendirme ölçekleri güvenilir kabul edilmiştir. Öğrenci öz değerlendirmesi ölçeği ise bu kriteri karşılamadığından ölçek olarak diğer analizlerde kullanılmamıştır.

\section{Tablo 3}

\section{Cronbach Alpha Güvenirlik Katsayıları}

Cronbach Alpha

\begin{tabular}{|c|c|c|c|c|c|c|c|c|}
\hline & $\begin{array}{l}\overline{\dot{\omega}} \\
\vec{\Delta}\end{array}$ & $\begin{array}{l}\stackrel{v}{b} \\
\dot{\omega} \\
\stackrel{\Delta}{0}\end{array}$ & $\begin{array}{l}m \\
\dot{\omega} \\
\tilde{\omega}\end{array}$ & $\begin{array}{l}+ \\
\dot{b} \\
\dot{\omega} \\
0\end{array}$ & $\begin{array}{l}n \\
n \\
\dot{\omega} \\
0\end{array}$ & $\begin{array}{l}0 \\
\dot{\omega} \\
\dot{\omega} \\
0\end{array}$ & $\begin{array}{l}\hat{\omega} \\
\dot{\omega} \\
0\end{array}$ & 至 \\
\hline Öğrenci Öz Değerlendirme & 0.47 & 0.25 & 0.22 & 0.14 & 0.57 & 0.45 & 0.43 & 0.30 \\
\hline Ders Değerlendirme & 0.72 & 0.69 & 0.60 & 0.76 & 0.79 & 0.68 & 0.81 & 0.75 \\
\hline Öğretim Elemanı Değerlendirme & 0.86 & 0.85 & 0.86 & 0.83 & 0.84 & 0.88 & 0.94 & 0.91 \\
\hline
\end{tabular}

Tablo 4'de ögrrencilerin 7 derse ait not ortalamaları ile bu 7 ders ve derslere giren öğretim elemanlarına ait memnuniyet düzeyleri arasındaki ilişkiyi gösterir korelasyon analizi sonuçları gösterilmiştir.Bu ilişki, 5 şubeninin 7 derse ait değerlendirmeleri olduğundan 35 ders değerlendirmesi, 35 öğretim elemanı değerlendirmesi ve 35 ders notu ortalaması üzerinden yapılmıştır. Bulgular, hem derslere ait memnuniyet düzeyleri ve ders notları ortalamaları arasında hem de öğretim elemanlarına ait memnuniyet düzeyleri ve ders notları ortalamaları arasında 0.01 düzeyinde anlamlı, pozitif yönlü ve güçlü bir ilişki olduğunu göstermiştir. Bu bulgulara göre öğrencilerin derslere ve öğretim elamanlarına ait memnuniyet düzeyi arttıkça bu derslere ait not ortalamaları da artmaktadır. Bu bir ilişki analizi olduğu için ders notu ortalamaları arttıkça derslere ve öğretim elamanlarına ait memnuniyet düzeylerinin de arttığı söylenebilir. 
Tablo 4

Korelasyon Analizleri ( $r$ )

\begin{tabular}{lc}
\hline \multicolumn{1}{c}{ Değişken } & Ders Notları Ortalaması \\
\hline Ders Değerlendirme & $0.25^{*}$ \\
& $0.62 * *$ \\
$\quad$ Öğretim Elemanı & \\
Değerlendirme & \\
$\mathrm{N}=35$ & \\
$*$ Değişkenler arasındaki ilişki 0.05 seviyesinde anlamlıdır. \\
$* *$ Değişkenler arasındaki ilişki 0.01 seviyesinde anlamlıdır.
\end{tabular}

Öğrencilerin derslere ve öğretim elemanlarına ait memnuniyet düzeylerinin not ortalamalarını ne kadar etkilediğini ölçmek için Çoklu Regresyon analizi yapılmış ve sonuçlar Tablo 5 'te gösterilmiştir. Bulgular bu iki bağımsız değişkenin not ortalamaları üzerinde 0.01 düzeyinde anlamlı etkileri olduğunu ve \%59'luk bir varyans açıkladığını göstermektedir. Açıklanan bu varyans düzeyi öğrencilerin derslere ve öğretim elemanlarına ait memnuniyet düzeylerinin derslerin not ortalamalarına oldukça yüksek düzeyde etki ettiğini işaret etmektedir.

Tablo 5

Ders Notları Ortalaması Üzerine Değerlendirme Türlerinin Etkileri

\begin{tabular}{ccccc}
\hline$R$ & $R^{2}$ & Adjusted $R^{2}$ & Stand. Err. of Est. & $F$ \\
\hline 0.79 & 0.62 & 0.59 & 12.3 & $17.1^{*}$
\end{tabular}

$\mathrm{N}=35$

a. Bağımsız değişken: Ders Notları Ortalaması

b. Bağımsız değişken: Öğrenci Öz Değerlendirme, Ders Değerlendirme ve Öğretim Elemanı Değerlendirme

*. Değişkenler arasındaki ilişki 0.01 seviyesinde anlamlıdır.

Son olarak Tablo 6'da öğrencilerin derslere ve öğretim elemanlarına ait memnuniyet düzeylerinin derslerin not ortalamalarına etkileri ayrı ayrı gösterilmiştir. Bulgular bu iki bağımsız değişkenin de not ortalamaları üzerinde 0.01 düzeyinde anlamlı etkileri olduğunu göstermektedir. Beta değerlerine bakıldığında, öğretim elemanlarına ait memnuniyet düzeylerinin not ortalamaları üzerindeki etkisinin derslere ait memnuniyet düzeyininkinden daha yüksek olduğu görülmektedir. VIF değerlerinin 10'dan küçük olması Çoklu Regresyon analizlerinin çoklu eşdoğrusallık (multicollinearity) probleminden etkilenmediğini göstermektedir (Field, 2005). 
Tablo 6

Ders Notları Ortalamasını Etkileyen Değerlendirme Türlerinin Etki Dereceleri

\begin{tabular}{lll}
\hline Değişken & Beta & VIF \\
\hline Ders Değerlendirme & $0.9^{*}$ & 3.3 \\
Öğretim Elemanı Değerlendirme & $1.3^{*}$ & 3.7 \\
\hline
\end{tabular}

$\mathrm{N}=35$

*. Değişkenler arasındaki ilişki 0.01 seviyesinde anlamlıdır.

\section{Sonuç ve Tartışma}

Eğitim kurumlarının en önemli paydaşı olan öğrencilerin memnuniyet düzeyinin ölçülmesi, eğitim sisteminin aksayan yönlerini bulmak, etkili iyileştirme yapmak ve eğitimin kalitesini arttırabilmek için kullanılabilecek önemli bir araçtır. Bu araştırmada, bir PMYO'da eğitim gören 2. sınıf öğrencilerinin aldıkları derslere ve bu derslerin öğretim elemanlarına ilişkin memnuniyet düzeyleri ölçülmüştür. Ayrıca bu araştırmada, literatürde nadiren ele alınan öğrenci memnuniyet düzeyinin akademik başarıya olan etkileri de incelenmiştir.

Araştırmadan elde edilen bulgular öğrencilerin derslerinden ve bu dersleri veren öğretim elemanlarından iyi düzeyde memnun olduklarını göstermiştir. Ancak, öğretim elemanlarına ilişkin memnuniyet düzeyi (4.2) derslere ilişkin memnuniyet düzeyinden (3.8) daha yüksek olarak bulunmuştur. Derslerle ilgili en yüksek memnuniyet düzeyi derslerin amacına uygunluğu boyutunda ölçülürken, en düşük derslerin yapıldığ fiziksel ortamın uygunluğu boyutunda ölçülmüştür. Öğretim elemanları ile ilgili ise en yüksek ögrretim elemanının ders konusuna vakıf olması boyutunda ölçülürken, en düşük kalıcılığı sağlayıcı tekrarlar yapmaları boyutunda ölçülmüştür. Bulgular, öğrencilerin hem derslere ilişkin hem de öğretim elemanlarına ilişkin memnuniyet düzeylerinin derslere ve öğretim elemanlarına göre anlamlı derecede farklılaştığını göstermiştir. Bir diğer ifadeyle, farklı dersler ve farklı öğretim elemanları öğrencilerde farklı düzeylerde memnuniyet meydana getirmektedir. Bu da dersin ve öğretim elemanının niteliğinin ve kalitesinin öğrencilerin memnuniyet düzeylerini etkilediğine işaret etmektedir.

Bulgular ayrıca, öğrencilerin derslere ve öğretim elemanlarına ilişkin memnuniyet düzeyleri ile bu derslere ait not ortalamaları arasında pozitif yönlü, anlamlı ve güçlü bir ilişki olduğunu göstermiştir. Derslere ve öğretim elemanlarına ilişkin memnuniyet düzeyleri, not ortalamaları üzerinde \%59'luk oldukça yüksek oranda bir varyans açıklamaktadır. Öğrencilerin öğretim elemanlarına ilişkin memnuniyet düzeyinin not ortalamaları üzerindeki etkisi derslere ait memnuniyet düzeyinin etkisinden daha fazla olarak bulunmuştur. Bu bulgular, öğrencilerin derslere ve öğretim elemanına ait memnuniyet düzeyleri arttıkça akademik başarılarının da arttığını göstermektedir. Bir diğer ifadeyle, eğitim kurumlarında derslerin ve öğretim elemanlarının nitelikleri ve kaliteleri yükseltildikçe öğrencilerin akademik başarıları da yükseltilebilecektir. 
Araştırmanın bulguları alanda yapılmış daha önceki çalışmaların bulgularıyla büyük oranda paralellik göstermektedir. Önceki araştırmalar da benzer olarak öğrencilerin, öğretim elemanlarının derslere zamanında ve hazırlıklı gelmeleriyle ve ders anlatma yeterlilikleriyle ilgili olarak yüksek düzeyde memnun olduklarını bulmuşlardır (Ekinci ve Burgaz, 2007; İçli ve Vural, 2010; Kaya ve Engin, 2007; Sökmen, 2011). Yine bu araştırmanın bulgularıyla benzer olarak, öğretim elemanlarına ilişkin memnuniyet düzeyini derslere ilişkin memnuniyet düzeyinden daha yüksek olarak tespit eden araştırmalar vardır (İçli ve Vural, 2010; Kaya ve Engin, 2007; Şahin, 2009; Yağc1 ve diğerleri, 2007).

$\mathrm{Bu}$ araştırmanın önceki araştırmalarla en çok paralellik gösteren bulgusu, öğrencilerin memnuniyet düzeylerinin dersten derse ve öğretim elemanından öğretim elemanına farklılaşmasıdır. Önceki pek çok araştırma bu bulguyu desteklemektedir (Burgaz ve Ekinci, 2007; Ekinci ve Burgaz, 2007; İçli ve Vural, 2010; Kaya ve Engin, 2007; Özgüngör, 2008; Sökmen, 2011; Şahin, 2009; Yağc1 ve diğerleri, 2007). Bu bulgu öğrencilerin, derslerle ve öğretim elemanlarıyla kendilerine verilen hizmetin kalitesini ve niteliğini değerlendirdiğini, bunları önemsediğini ve bunlara uygun bir tepki ürettiğini göstermektedir. $\mathrm{Bu}$ yönüyle de öğrenci memnuniyeti üzerine yapılan çalışmaların amacına uygunluğu doğrulanmaktadır.

\section{Öneriler}

Hem bu araştırmanın bulguları hem de önceki araştırmanın bulguları öğrencilerin kendilerine verilen hizmeti önemsediğini ve buna göre bir tutum geliştirdiklerini göstermektedir. Bu bulgular, öğrencilerin hizmet kalitesi algısıyla memnuniyet düzeyleri arasındaki pozitif yönlü bir ilişkiye işaret etmektedir (Okumuş ve Duygun, 2008). Bu nedenle eğitim kurumları, en önemli müşterileri olan öğrencilerin memnuniyetini arttırmak için hem derslerde sunulan imkân ve şartları hem de öğretim elemanlarının nitelik ve kalitesini yükseltmelidirler. Daha önce yapılan çalışmalar bu konularda yapılan iyileştirme ve geliştirmelerin öğrencilerin memnuniyetini artırdığını göstermiştir (Yıldız ve diğerleri, 2006).

Okumuş ve Duygun (2008) öğrenci memnuniyetini artırmak için eğitim ortamının fiziksel şartlarının iyileştirilmesi gerektiğini, kaliteli öğretim elemanı istihdamı yapılması gerektiğini, öğrencilerin ihtiyaç ve beklentilerine önem verilmesi gerektiğini, onlara karşı saygılı olunması gerektiğini ve onları daha iyi anlayabilmek için empati yapılması gerektiğini vurgulamaktadır. Ekinci ve Burgaz (2007) da Eğiticilerin Eğitimi Programlarının niteliğinin geliştirilmesini ve eğitim programlarının beklentiler dikkate alınarak yenilenmesini önermiştir. Öğrenci memnuniyetinin sağlanması ve sürdürülmesi için dikkat çekilen bir diğer önemli konu da yapılan iyileştirme ve geliştirmelerin sürekli olması gerektiğidir (Kaya ve Engin, 2007; Şahin, 2009).

Yapılan iyileştirme ve geliştirmelere zemin hazırlamak üzere öğrenci memnuniyet düzeyleri de belirli aralıklarla ölçülmelidir. Elde edilen bulgular da fakültelerle, öğretim elemanlarıyla ve öğrencilerle paylaşılmalıdır (Ekinci ve Burgaz, 
2007; Şahin, 2009).Memnuniyeti ölçmek ve memnuniyetsizlik yapan etkenleri bulmak hizmet kalitesini ve verimi arttırmak için yararlı bir araçtır, ancak bunu ölçmenin riskli bir yanı da vardır (Şahin, 2009). O da bu sürecin memnuniyeti ölçülenlerde bir beklentiye neden olmasıdır. Bu beklenti karşılanmaz ve hizmet kalitesi iyileştirilmezse memnuniyetsizliğin daha da artma riski vardır. Bu nedenle ne yapılması planlandığı ve takip eden süreçte nelerin yapıldığı paydaşlara ayrıntılarıyla anlatılmalıdır (Şahin, 2009).

$\mathrm{Bu}$ araştırmada eğitim hizmetlerinin kalitesinin artırılmasına katkı yapmak amacıyla bir PMYO'da eğitim alan öğrencilerin memnuniyet düzeyleri ölçülmüş ve önemli bulgular elde edilmiştir. Ancak, her bilimsel araştırmanın olduğu gibi bu araştırmanın da bazı kısıtları bulunmaktadır. Bu araştırma sadece bir PMYO'da ve 185 öğrenciyle yapılmıştır. Araştırmanın bulguları değerlendirilirken bu kısıt dikkate alınmalıdır. Ayrıca, öğrenci memnuniyeti ile akademik başarı arasındaki ilişki incelenirken öğrencilerin, derslerle ilgili elde ettikleri nihai not ortalamasından etkilenmemeleri için anketler öğrenciler final sınavına girmeden dağıtılmış, ilişki analizleri ise final notları da kullanılarak yapılmıştır. Bununla beraber öğrencilerin, dersleri ve öğretim elemanlarını değerlendirirken veriler toplanmadan önce oldukları 1. vize sınavlarından etkilenme olasılıkları vardır. Öğrenci memnuniyeti ve akademik başarı ilişkisini gösterir bulgular da bu kısıt dikkate alınarak değerlendirilmelidir.

Öğrenci memnuniyeti araştırmaları ülkemizde sıklıkla yapılmaktadır. Ancak öğrenci memnuniyeti ve akademik başarı arasındaki ilişkiyi inceleyen araştırmalar sınırlıdır. Gelecekteki araştırmalar bu araştırmanın kısıtlarını da dikkate alarak bu alana daha çok yoğunlaşmalıdırlar. 


\section{Kaynakça}

Atay, L., \& Yıldirım, H. M. (2009). Determining factors that affect satisfaction of students in undergraduate tourism education. TOURISMOS: An International Multidisciplinary Journal of Tourism, 5(1), 73-87.

Briggs, S. (2006). An exploratory study of the factors influencing undergraduate student choice: The case of higher education in Scotland. Studies in Higher Education, 31(6), 705-722.

Burgaz, B., \& Ekinci, C. E. (2007). Öğrencilerinin Hacettepe Üniversitesi’nce sunulan hizmetlere ilişkin beklenti ve memnuniyet düzeyleri. Hacettepe Üniversitesi İktisadi ve İdari Bilimler Fakültesi Dergisi, 25(1), 71-89.

Düren, Z. (2000). 2000'li yıllarda yönetim. İstanbul: ALFA Basım Yayım Dağıtım Ltd. Sti.

Ekinci, C. E., \& Burgaz, B. (2007). Hacettepe Üniversitesi öğrencilerinin bazı akademik hizmetlere ilişkin beklenti ve memnuniyet düzeyleri. Hacettepe Üniversitesi Ĕgitim Fakültesi Dergisi, 33, 120-134.

Emanuel, R., \& Adams, J. N. (2006). Assessing college student perceptions of instructor customer service via the quality of instructor service to students (QISS) questionnaire. Assessment \& Evaluation in Higher Education, 31(5), 535-549.

Ensari, H., \& Onur V. (2002). Kaliteye ilişkin öğrenci beklentileri: Eğitim fakülteleri örneği. Amme İdaresi Dergisi, 145-153.

Ertürk, S. (1972). Eğitimde program geliştirme. Ankara: Yelkentepe Yay.

Field, A. (2005), Discovering statistics using SPSS: Second edition, Thousands Oak, CA: SAGE Publications Inc.

Gömleksiz, M. N. (2002). Modüler öğretime ilişkin bir tutum ölçeğinin geçerlik ve güvenirliği. Firat Üniversitesi Sosyal Bilimler Dergisi, 12(2), 275-285.

Guolla, M. (1999). Assessing the teaching quality to student satisfaction relationships: Applied customer satisfaction research in the classroom. Journal of Marketing Theory and Practice, 7, 87-97.

Işık, F. (2012). Uluslararası öğrenci yetiştirme sürecinde öğrenci memnuniyetine ilişkin karş1laştırmalı analiz. Hacettepe Üniversitesi Eğitim Fakültesi Dergisi, Özel Sayl: 2, 25-34.

İçli, G. E., \& Vural, B. B. (2010). Toplam kalite yönetimi ve uygulamaları çerçevesinde Kırklareli Üniversitesi meslek yüksekokulları öğrenci memnuniyeti araştırması. Marmara Üniversitesi İ.I.B.F. Dergisi, XXVIII(I), 335-349.

Kaya, İ. ve Engin, O. (2007). Yüksek öğretimde kalite iyileştirme sürecinde öğrenci memnuniyetinin ölçülmesine yönelik bir araştırma. Milli Eğitim, C.174, 106-115. 
Nunnally, C. (1978). Psychometric theory. New York, NY: McGraw-Hill.

Okumuş, A., \& Duygun, A. (2008). Eğitim hizmetlerinin pazarlanmasında hizmet kalitesinin ölçümü ve algılanan hizmet kalitesi ile öğrenci memnuniyeti arasındaki ilişki. Anadolu Üniversitesi Sosyal Bilimler Dergisi, 8(2), 17-38.

Özgüngör, S. (2008). Öğrencilerin öğretim türü, program türü ve fakülteyi tercih nedenlerine göre fakülte yaşamından aldıkları doyum düzeyleri. Pamukkale Üniversitesi Ĕ̈itim Fakültesi Dergisi, 2(24), 80-91.

Parasuraman, A., Zeithaml, V. A., \& Berry, L. L. (1985). A conceptual model of service quality and its implications for future research. Journal of Marketing, 49, 41-50.

Politis, Y., \& Siskos, Y. (2004). Multicriteria methodology for the evaluation of Greek engineering department. European Journal of Operations Research, 156, 223-240.

Popli, S. (2005). Ensuring customer delight: A quality approach to excellence in management education. Quality in Higher Education, 11(1), 17-24.

Sahney, S., Banwet, D.K., \& Karunes, S. (2004). Customer requirement constructs: the premise for TQM in education: A comparative study of select engineering and management institutions in the Indian context. International Journal of Productivity \& Performance Management, 53(6), 499-520.

Sökmen, A. (2011). Öğrenci memnuniyetine yönelik Ankara'daki bir meslek yüksekokulunda araştırma. Işsletme Araştırmaları Dergisi, 3(4), 66-79.

Şahin, A. E. (2009). Eğitim fakültesinde hizmet kalitesinin eğitim fakültesi öğrenci memnuniyet ölçeği ile değerlendirilmesi. Hacettepe Üniversitesi Eğitim Fakültesi Dergisi, 37, 106-122.

Shavelson, R. J. (1996). Statistical reasoning for the behavioral sciences (3rd ed.). Needham, MA: A Simon \& Schuster Company.

Tatlı, Z. H., Kokoç, M., \& Karal, H. (2011). Bilgisayar ve öğretim teknolojileri eğitimi bölümü öğrencilerinin memnuniyet durumları: Karadeniz Teknik Üniversitesi örneği. İlköğretim Online, 10(3), 836-849.

Tok, A., \& Sontay, S. (2006). Mesleki eğitimde öğrenci memnuniyeti ve etkili öğretim. Milli Ĕgitim, 172, 106-115.

Uzgören, N., \& Uzgören E, (2005). Dumlupınar öğrencileri lisans öğrencilerinin memnuniyetini etkileyen bireysel özelliklerin istatistiksel analizi: Hipotez testi, kikare testi ve doğrusal olasıl1k modeli. http://sbe.dumlupinar.edu.tr/17/173-192.pdf, (Erişim Tarihi: 01.05.2013).

Yağc1, E., Ekinci, C. E., Burgaz, B., Kelecioğlu, H., \& Ergeneyurt, T. (2007). Yurt dışına giden Hacettepe Üniversitesi ERASMUS öğrencilerinin memnuniyet düzeyleri. Hacettepe Üniversitesi Ĕ̌itim Fakültesi Dergisi, 33, 229-239. 
Yenersoy, G. (1997). Toplam kalite yönetimi. İstanbul: Rota Yayın Yapım Tanıtım Ticaret Ltd.

Yeşilyaprak, B. (2002). Eğitimde rehberlik hizmetleri (Gözden Geçirilmiş 4. Bask1). Ankara: Nobel Yayıncilık.

Yıldız, S. M., Erdemir, İ., \& Gitmez, M. (2006). Bir orta öğretim kurumunda toplam kalite yönetimi öğrenci memnuniyeti üzerine etkisinin incelenmesi. Milli Ĕgitim, $172,143-154$. 